\title{
The Value of Social Care Character Education Through Merindu Baginda Nabi
}

\author{
Alfa Rosyid Abdullah ${ }^{1}$, Herman J. Waluyo², Nugraheni Eko Wardani ${ }^{3}$ \\ ${ }^{1,2,3}$ Postgraduate te of Sebelas Maret University, Indonesia \\ alfarosyid.ab@gmail.com
}

\begin{abstract}
Character education is a form of cultivation of noble character in students. The aspect of 'social care' character is one of the most important of the eighteen character education in Indonesia, this is because the sense of sensitivity and help towards others in the environment around students begins to diminish. There are various kinds of media to succeed in internalizing character education, one of which is a novel. The novel Merindu Baginda Nabi by Habiburrahman El-Shirazy can be said to be a complete novel in instilling character in Indonesia. Therefore, researchers will explore how the value of social care character education in the novel Merindu Baginda Nabi. The research method used is qualitative descriptive qualitative research. The novel Merindu Baginda Nabi as a source of data in this study, in the form of dialogue and narrative stories about character education about social care. Based on the results of the analysis, seventeen data were found that were divided into four important parts, namely: giving help to others, caring for others, mutual respect, and sympathy.
\end{abstract}

Keywords : Character Education; Social Care; Merindu Baginda Nabi Novel

\section{Introduction}

Character education is a learning to be virtuous and good morals. Nobility and morality are based on the concepts of the state and values in society to be instilled in students. This was held as a form of mutual concern to overcome moral depravity in Indonesia which was eroded by the presence of increasingly rapid technology. Chandra (2019) revealed that the internalization of character education in young people is intended as a form of the nation's seriousness in producing a superior and moral generation. Setiawati (2017) added that character education has a general goal to develop students so they can make good and bad decisions, maintain, realize and spread goodness.

Republic of Indonesia presidential regulation no 28 of 2017 states that the division of character education is divided into eighteen aspects. One of the most important character education of the eighteen is social care character education. By definition, Kemdiknas (2010) defines social care as attitudes and actions that always want to provide to help others and people in need. Masrukhan (2016) said that social care character education is held because empathy for others has faded, examples of selfish attitudes, indifference to the condition of friends, student fights, caring please help friends and so on.

Internalization of character education for students can be done in various ways and media. Starting from direct learning, field learning, writing media at school through literary works. Khomsilawati (2017) argues that character education is launched to present philosophical values and to present the whole character of the nation as a whole and overall, both self-character and national character. The goals of character education can be achieved also without going through many methods or a new program, with cultural and social transformation can also be carried out a character education. As stated by Mudlofir (2013) that to achieve the effectiveness of character education can be done through cultural and social transformation into schools. 
Literary work is a form of an author's idea to convey impressions through the interaction of the author's thoughts and social facts. Hasanah (2017) argues that a literary work is created from the author's dialogue and social culture that exists in society through intellect, thought and even the emotions of the author. Ratna (2013) also believes that literary works describe people's lives and can to give a certain meaning.

Literary works also have a very deep message to convey the thoughts of the author about a socio-cultural form that exists in society, no wonder if the novel is said to be a complete enough literary work in giving messages to the audience. As revealed by Minderop (2013) that literature can entertain and have a life and moral value to enhance the experience, moral awareness, spiritual and emotional emotions of the reader. Wibowo (2013) also revealed that a writer can shake and change the world, influence, enchant and hypnotize and even provoke readers by following literary ideas and ideas. So, literary works can be said to have a very important contribution in the development of students' character through messages either implied or implied in a literary text in the form of a novel or the other.

The novel as a literary work that has complete moral messages from various aspects of life that an author wants to convey, so that it can be said as a work that is complete enough to convey several messages, including character education. Tantri (2017) that character education is delivered with novels because novels are the most effective literature in explaining some moral values. Setiawan (2018) also believes that through the novel, the author invites the reader to live and capture a phenomenon of life, the social environment in the novel is the embodiment of the culture and customs of the community.

From various novels in Indonesia, the novel Merindu Baginda Nabi by Habiburrahman El Shirazy was written by a famous writer about religious and moral novels. This novel comes by telling the life of an outstanding teenager named Rifa, as a high school student in Indonesia who passed the exchange of students to America is a matter of pride. In addition, this character also provides an example of how good character and positive moral behavior. Although in this novel also told the antagonistic figures who harmed Rifa, but because of Rifa's determination and patience, he can continue to survive and give a very good message to his readers. Therefore, this novel is considered appropriate as a media channeling the character education of students.

\section{The Value Of Social Care Character Education}

Character education is an educational effort in developing a good character based on virtues objectively both for themselves and the community (Saptono 2011). Agreeing with that, Otaya (2014) argues that character education is a conscious effort undertaken in shaping students to become positive personalities, with moral values referring to graduate competency standards (SKL) so that they can be implemented in everyday life. In detail, Lickona (2013) mentions that character education includes three important things, namely first, moral knowledge in the form of moral awareness, moral value knowledge, moran thought, decision making, and personal knowledge; second, moral feelings about conscience, self-esteem, empathy, loving good things, self-control and humility; and 3) moral actions in the form of competencies, desires, and habits.

Character education in Indonesia has eighteen aspects taught to students, the Ministry of National Education (2010) outlines some of the aspects as follows: (1) religious, (2) honest, (3) tolerance, (4) discipline, (5) hard work , (6) creative, (7) independent, (8) democracy, (9) curiosity, (10) national spirit, (11) patriotism, (12) respect for achievement, (13) friendly / 
communicative, ( 14) peace-loving, (15) fond of reading, (16) caring for the environment, (17) caring socially and (18) responsible. The purpose of character education is to form a strong, competitive, noble, moral, tolerant, mutual cooperation, patriotic-spirited, dynamicdeveloping, science-and-technology-oriented nation that is all imbued with faith and piety to God Almighty based on Pancasila (Hamani, Muhlas, and Hariyanto 2011).

Social care character education is an attitude of someone sensitive to what is around him, both sensitive to the community and family. Fauzi, et al (2017) revealed that social care is an action to care for the surrounding social environment so that students are always motivated to help others in need. Suwanto (2018) also believes that character education care about the environment is an important aspect that must be raised in students to have a sense of sensitivity to the surrounding conditions and mutual respect.

\section{Research Methods}

This type of descriptive qualitative research was used in this study. The novel Merindu Baginda Nabi by Habiburrahman El Shirazy was published in November 2018 as a research object. The data in this study are in the form of narration and dialogue between characters. The technique of data collection is done by content analysis method. Moleong (2014) explains that this data collection technique is used for reference that is reliable and valid with respect to the context. The validity of the data uses triangulation in three aspects, namely: triangulation of theories, methods and data sources. The data analysis technique was carried out with the flow model analysis technique from Miles and A.M. (2012) in the form of reduction, data presentation, and conclusion drawing.

\section{Findings and Discussion}

This research uses social care character education theory as a basis for studying the novel Merindu Baginda Nabi by Habiburrahman El Shirazy. Researchers found a total of sixteen data on social care character education divided into four aspects, namely 1) giving help to others, 2) caring for others, 3) mutual respect, and 4) sympathy. In full will be explained in the following explanation.

\subsection{Give Help to Others}

Helping others is an obligation to ease someone's burden, whether it is a disaster, disaster, or distress. In this novel, the researcher found six data regarding help in others, a clear description will be elaborated in the following explanations.

The manifestation of social care about giving help to others is exemplified by Tentrem, a grandmother selling rice often giving help to people in need. even, he is willing to help and care for Rifa when finding her in a trash can, as described in the following quote.

The grandmother saved her before heavy rain fell. If the heavy rain falls and he is still in the trash, somehow the fate of his condition. He did not know. (El-Shirazy: 2)

In the quote explained how Rifa existed, he was found by a grandmother named Tentrem. Despite the shortcomings, the grandmother sincerely wanted to care for the little Rifa. Mbah Tentrem is famous for generous people, sincere, and like to help, as expressed in the following quote. 
Almost everyone acknowledges that the simple Mbah Tentrem is sincere, helpful, and kind to anyone. (El-Shirazy: 3)

... And when it comes to generous matters, perhaps from this village one of the most generous people. This mosque stands on waqf land. Subhanallah, from selling pecel rice, it can endow land for the mosque "(El-Shirazy: 4)

Mbah Tentrem teaches readers that being generous does not have to have abundant wealth, even though he only sells rice, he can to give waqf land and give help to others. The form of helping others is also done by the figures of Mr. Nur and Mrs. Sal, as in the following quote.

Then God sent a husband and wife with angels who he now knew as his parents. People nodded at them, Mr. Nur and Mrs. Sal or Mrs. Salamah. A married couple who have been married for eight years but are not also blessed with offspring. Pak Nur and Mrs. Sal begged to win to Mbah Tentrem that they would be allowed to care for and care for him ... (El-Shirazy: 3)

The quotation explains how Rifa when she was a baby, she was adopted from the hands of Mbah Tentrem, thanks to the adoption, care, care and training of Pak Nur and Bu Sal, Rifa became an outstanding child. The figures Pak Nur and Bu Sal teach social care, how important it is to help that will make happy in the future, open he is happy to have children who excellike Rifa. The form of help to others is also exemplified by the character Pak Nur, in the following quote.

... but things that are related to please help social relations he was able to, for example, asked to give a speech as a representative in-law, representative shahibul hajat, and the like ... (El-Shirazy: 53)

The quote explains how Pak Nur helped the local community to give a speech at the engagement event like a family representative, this is a small form of help, even though no money was spent, but the service makes people happy to be helped in their event. The form of support for others is also exemplified by Mr. Nur in the following quote.

"Mrs. Marti, it is impossible for me to use the money of orphans to cover Mijan's treatment, your child. Here I have five hundred thousand. Please use! ... "(El-Shirazy: 69)

The quotation explains that Pak Nur was willing to set aside some of his money to help Darmijan who was injured due to being beaten by residents after being caught stealing in the village. Darmijan figure is also an evil figure, he had abused Rifa, ruined the atmosphere of the pesantren. Pak Nur teaches the reader, how to character education 'social care' about helping others must be done even though that person has done something that is not good for us. 


\subsection{Care for Others}

Concern for fellow humans is an attitude that needs to be applied to students. This is needed to increase students' sensitivity to the situation of friends, relatives, and family around them. In this novel, researchers found four data about this, which will be described as follows.

One of the caring attitudes of others is exemplified by the Rifa figure, as expressed in the following quote.

"I could not leave the orphans." (El-Shirazy: 8)

In the quote happened when Rifa was invited by his friends to join the exchange of students abroad, he felt sorry for the orphans he fostered at the pesantren. He refused the invitation. This shows the attitude of caring for others, showing a feeling of wanting to care for people who need it. Attitudes of concern were also shown by Rifa and the seminar committee, which is exemplified in the following quote.

"The idea is very good. I suggested the theme of pornography and its effect on the brain development of children and adolescents. That fits Ruth's fist perfectly. I will tell the mayor about this seminar so that it is supported ... "(El-Shirazy: 98)

The quotation explains that Rifa and the committee are discussing the theme of the seminar which will be explained by prof. Ruth. Rifa and the committee agreed to carry the theme of pornography and the dangers of adolescents, it is a concern of the committee for the delinquency of today's youth due to the presence of increasingly rapid technology. The quote teaches the reader that caring for others can also be applied by giving programs that improve morale in society. Another figure, Mr. Nur also has a high sense of concern as expressed in the following quote.

... Abah can not let go of foster children without a clear path and plan. He contacted some of his acquaintances in Jakarta ... (El-Shirazy: 14)

The quotation explains that Mr. Nur's foster children have graduated from the pesantren and will migrate to Jakarta, but Mr. Nur does not just let go of his foster children, he still cares for him to have a good life overseas. Mr. Nur contacted his acquaintance in Jakarta, so they could be directed properly. This attitude shows that Mr. Nur has a high concern for his foster children, he does not arbitrarily release foster children to migrate. Attitudes of concern for others are also shown by Rifa's friends in the following quote.

All friends and students of the 33rd National High School warmly welcomed Rifa's presence at the school, except Arum. The beautiful girl did not use Rifa at all. Arum did not look at all, nor did he convey any concern over what had happened to Rifa in the slightest. All his friends repeatedly pray for his recovery, except Arum. (ElShirazy: 85) 
The quote explains that Rifa's friends visited Rifa after the accident. Visiting the sick is a form of caring between humans, it teaches the reader how important caring is, it teaches social care character education.

\subsection{Mutual respect}

Mutual respect is an attitude of respecting the opinions or actions of others, with this attitude students are expected to be able to respect their friends and people around them. With mutual respect, there will be a high level of peace and will rarely clash in differences. In this study found as many as two came with an attitude of mutual respect. An example of this attitude is taught by Pak Nur in Rifa, as in the following quote.

Little things related to manners, how to respect people, please people, Abah is very caring. If you don't remind Abah, he might not buy souvenirs. Or buy only for Abah and Ummi only. And proven, Abah's suggestion was very useful. Everyone gets happy presents, even Mrs. Markonah hugs him while crying. (El-Shirazy: 27)

The quotation tells when Rifa returned from America, she was reminded to buy Abah souvenirs as a form of respect for people around. From this attitude, it will impress both because it pleases humans around it. Therefore, the author teaches how to respect each other in the novel. An example of mutual respect is also taught by Pak Nur in the following quote.

"My children, if we do good but are not considered by others, then let it go ahead and continue to do good. Our goal is not human, but Allah SWT. My children, be like the earth. Look at the sincerity of the earth ... "(El-Shirazy: 117)

The story in the quote explains how to respond to what people do to us, no matter how bad what happens we have to respect it so that no other bad things happen like fighting between fellow human beings. The example teaches how it is important to respect others even if anything happens to us so that it does not make matters worse.

\subsection{Sympathy}

Sympathy for others is a very important form of attitude. This attitude can be said as a sense of concern or condolences towards what befalls others, this attitude is important to instill in students to be sensitive to what is happening in the surrounding environment that requires comfort and support in a situation. The expression of sympathy is shown by Mbah Tentrem in the following quote.

"... Mbah Tentrem said," Mas, I will get my house, yes, if later I am not there, I will forgive orphans and abandoned children like the Dipah. Later, please pass on to my children, worry that I have forgotten this inheritance ', "(El-Shirazy: 4)

The quote explains how Mbah Tentrem felt sympathy and compassion for what happened to orphans and abandoned children like the Rifa figures, so he left the land and house to care for the abandoned children. This attitude is a sympathy of Mbah Tentrem which is very high, although he is among those who are not rich, he gave up land to give to others in need. This attitude of sympathy also continued with the children of Tentrem in the following quotation. 
... When the will of Mbah Tentrem was notified to her children, they all supported, they even contributed to build their dormitory and were ready to become permanent donors. (El-Shirazy: 4)

This quotation explains that the children of Tentrem highly appreciate the will of Mbah Tentrem so that they also sympathize with abandoned children, give up a charity and are ready to become donors to the pesantren which was established through the grandmother of Tentrem. Sympathy is also taught through the character Pak Nur in the following quote.

Actually, he did not want to deal with Mijan, but the arrival of Mrs. Marti who won the sobbing melted her heart. (El-Shirazy: 61)

"Why are you not willing, Fa? Poor him, even though he is our brother. You saw that her mother was crying like that. And I have promised to go there. "(El-Shirazy: 62)

The quote explains how Pak Nur's sympathy for Mrs. Marti who cried because of the accident. Mr. Nur did not look at what disaster, he rushed to help Mrs. Marti, even though the disaster happened to Mrs. Marti's son, the Mijan who was beaten by citizens for stealing, Mijan was also a thug who had hurt Rifa and caused riots in the pesantren. Another attitude of sympathy is conveyed by the author in the following story excerpt.

Some students seemed to be beginning to cry. Including Rifa, Retno, Ika, and Daru (El-Shirazy: 89)

The quotation tells the sympathy of Rifa and her friends because their teacher will leave school because of a problem, they feel sympathy for what happened to Mrs. Ririn. The messages conveyed by the writer through stories on some of these figures are about social care character education aspects of sympathetic attitudes towards others without having to look at how they are so that harmony between people will still be upheld.

\section{Conclusion}

Social care character education is an important attitude to foster students' sensitivity to the surrounding environment. With social care, it is expected that there will be a high harmony in the lives of students among several differences. Novel as one of the literary works is considered suitable as a media channeling social care character education, this is because the writer gives important moral messages in a work.

One of the phenomenal novels of the famous writer is the novel Merindu Baginda Nabi by Habiburrahman El-Shirazy. This novel tells the life of pesantren and fighters in achieving achievements, and the author inserts religious messages regarding virtue and positive morality. This research uses the novel Merindu Baginda Nabi as the object of study. From this study found seventeen social care character education data which are divided into four important aspects, namely 1) giving help to fellow humans, 2) caring for others, 3) mutual respect, and sympathy. From the findings of the researcher, it can be concluded that the novel Merindu Baginda Nabi is very suitable as a medium to foster social care attitudes towards students. 


\section{References}

Amalia, Wiwit Puji, Sumarwati, and Budhi Setiawan. 2019. "Pemanfaatan Nilai Peduli Sosial Cerita Rakyat Di Kabupaten Purbalingga Sebagai Pengembangan Pendidikan Karakter Dalam Pembelajaran Bahasa Indonesia." BASASTRA Jurnal Penelitian Bahasa, Sastra Indonesia dan Pengajarannya 6(2): 221-30.

Badan Litbang, Kementrian Pendidikan Nasional. 2010. Pusat Kurikulum, Pengembangan Pendidikan Budaya Dan Karakter Bangsa.

Chandra, Afry Adi, Herman J Waluyo, and Eko Wardani. 2019. "Nilai Pendidikan Karakter Religius Novel Sawitri Dan Tujuh Pohon Kelahiran Karya Mashdar Zainal : Perspektif Tradisi Islam Nusantara." Jurnal Lektur Keagamaan 17(1): 169-96.

Fauzi, Achmad Ryan, Zainuddin, and Rosyid Al Atok. 2017. "Penguatan Karakter Rasa Ingin Tahu Dan Peduli Sosial Melalui Discovery Learning." Jurnal Teori dan Praksis Pembelajaran IPS 2(2): 27-36.

Hamani, Muhlas, and Hariyanto. 2011. Konsep Dan Model Pendidikan Karakter. Bandung: PT. Remaja Rosdakarya.

Hasanah, Uswatun. 2017. "Nilai Moral Dalam Sāq Al-Bambū Karya Sa'ūd Al-San'ūsī." Adabiyyāt: Jurnal Bahasa dan Sastra I(1).

Khomsilawati, Saktya. 2017. "Penguatan Karakter Religius Dalam Pembelajaran Sastra Melalui Adaptasi Kearifan Lokal." Prosiding SENASBASA 1: 370-75.

Lickona, Thomas. 2013. Educating for Character: Mendidik Untuk Membentuk Karakter. Jakarta: PT Bumi Aksara.

Masrukhan, Ahsan. 2016. "Pelaksanaan Pendidikan Karakter Peduli Sosial Di SD Negeri Kotagede 5 Yogyakarta.” Jurnal Pendidikan Guru Sekolah Dasar 29: 812-20.

Miles, M.B, and Huberman A.M. 2012. Analisis Data Kualitatif. Jakarta: UI Press.

Minderop, Albertine. 2013. Psikologi Sastra: Karya Sastra, Teori, Dan Contoh Kasus. Jakarta: Yayasan Pustaka Obor Indonesia.

Moleong, Lexy J. 2014. Metodologi Penelitian Kualitatif. Bandung: PT. Remaja Rosdakarya.

Mudlofir, Ali. 2013. "Pendidikan Karakter: Konsep Dan Aktualisasinya Dalam Sistem Pendidikan Islam A . Pendahuluan Diakui Dalam Berbagai Aspek, Pendidikan Di Negeri Ini Mengalami Kemajuan . Sarana Dan Prasarana Sekolah Terus Mengalami Perbaikan . Peningkatan Anggaran Pendidi.” Nadwa: Jurnal Pendidikan Islam 7(2): 229.

Otaya, Lian G. 2014. "Pendidikan Karakter Berbasis Nilai." Nadwa: Jurnal Pendidikan Islam 8(1): 75.

Ratna, Nyoman Kuntha. 2013. Ratna, N. K. (2013). Teori, Metode, Dan Teknik Penelitian Sastra. Yogyakarta: Pustaka Pelajar.

Saptono. 2011. Dimensi-Dimensi Pendidikan Karakter: Wawasan, Strategi, Dan Langkah Praktis. Jakarta: Erlangga.

Setiawan, Arif. 2018. "Pandangan Hidup Wanita Jawa Dalam Novel Bekisar Merah Karya Ahmad Tohari." Jurnal Kredo 1(2): 106.

Setiawati, Nanda Ayu. 2017. "Pendidikan Karakter Sebagai Pilar Pembentukan Karakter Bangsa." In Prosiding Seminar Nasional Tahunan Fakultas Ilmu Sosial Universitas Negeri Medan, , 348-52.

Shirazy, Habiburrahman El. 2018. Merindu Baginda Nabi. Jakarta: Penerbit Republika 
Suwanto, Agus Heri. 2018. "Upaya Menumbuhkan Karakter Peduli Sosial Pada Siswa Kelas Atas Mi Muhammadiyah Bolon.” Naskah Publikasi, Pendidikan Guru Sekolah Dasar, Fakultas Keguruan dan Ilmu Pendidikan, Universitas Muhammadiyah Surakarta.

Tantri, Ade Asih Susiari. 2017. "Nilai-Nilai Pendidikan Karakter Dalam Novel Tantri (Perempuan Yang Bercerita) Karya Cok Sawitri Sebagai Alternatif Pembelajaran Sastra Di Sekolah Dasar." In Education and Language International Conference Proceedings Center for International Language Development of Unissula, , 57-68.

Wibowo, Agus. 2013. Pendidikan Karakter Berbasis Sastra. Yogyakarta: Pustaka Pelajar. 